\title{
Exploring the neurotoxicity and changes in life cycle parameters of Drosophila melanogaster exposed to arecoline
}

\author{
Barkha Shakya and Yasir Hasan Siddique* (D)
}

\begin{abstract}
Background: Arecoline (an alkaloid) has been reported as a potent cytotoxic as well as genotoxic agent but its neurotoxic effects are limited.

Material and methods: In the present study, we evaluated the neurotoxic effects and changes in life cycle parameters of Drosophila melanogaster on exposing the flies to 5, 10, 20, 40 and $80 \mu \mathrm{M}$ of arecoline for 5 days. After the exposure, the flies were assayed for climbing ability, activity pattern, oxidative stress markers, acetylcholinesterase (AChE), monoamine oxidase activity (MAO), caspase-3 and caspase-9 activities and apoptosis in the neuronal cells. For studying the effects on life cycle parameters, duration of pupation, emergence and life span were also studied.

Results: The exposure of flies to 5 and $10 \mu \mathrm{M}$ of arecoline did not show toxic effects, but the flies exposed to 20, 40 and $80 \mu \mathrm{M}$ showed a significant dose-dependent loss of climbing ability, activity pattern, MAO, glutathione (GSH) content and acetylcholinesterase activity and increase in the glutathione-S-transferase (GST), MAO activity, lipid peroxidation assay (LPO), protein carbonyl content (PCC), caspase-3 and caspase-9 activities and apoptosis in the neuronal cells. The exposure of flies to arecoline not only results in the delay of pupation but also delayed the emergence of flies. A significant reduction was also observed in the life span of flies exposed to 20,40 and $80 \mu \mathrm{M}$ of arecoline. The eyes of flies emerged from the larvae exposed to various doses of arecoline were also analysed for the phenotypic abnormality. Clear dose-dependent deformities were observed in the eyes of the flies emerged from the exposure of larvae exposed to 20, 40 and $80 \mu \mathrm{M}$ of arecoline.
\end{abstract}

Conclusion: Arecoline not only is a neurotoxic agent but also affects the life cycle parameters of the fly.

Keywords: Arecoline, Drosophila, Oxidative stress, Pupation, Emergence, Life span, Apoptosis

\section{Background}

Arecoline, a main areca alkaloid of the betel nut, has been reported to be cytotoxic as well as genotoxic in cultured cells (in vitro), mice and rats (in vivo) (Kumpawat, Deb, Ray, \& Chatterjee, 2003; Chou et al., 2009; Kevekordess et al., 2001; Dasgupta et al., 2006; Zhou, Sun, Yang, \& Zhang, 2014; Run-mei, Jun-jun, Jing-ya, Li-juan, \& Yong, 2014). Arecoline is highly effective against tapeworms, cysticercus, Fasciola hepatica. It is also effective in treating cardiovascular diseases due to its vasorelaxation, anti-thrombosis and anti-antherogenic effects (Liu, Peng,

\footnotetext{
* Correspondence: yasir_hasansiddique@rediffmail.com

Drosophila Transgenic Laboratory, Section of Genetics, Department of Zoology, Faculty of Life Sciences, Aligarh Muslim University, Aligarh, Uttar Pradesh 202002, India
}

$\mathrm{Hu}, \mathrm{Xu}, \& \mathrm{Wu}, 2016)$. The prolonged exposure of arecoline leads to the oral submucous fibrosis and oral cancers (Fareed, Afzal, \& Siddique, 2011; Jyoti et al., 2014; Jyoti, Khan, Afzal, Naz, \& Siddique, 2013; Jyoti, Siddique, Khan, Naz, \& Ali, 2015). The pharmacology, toxicology and potential applications of arecoline have been extensively reviewed by Liu et al. (2016). It has also been reported to cross the blood brain barrier and is therefore used as a potential therapeutic action against the symptoms of schizophrenia and Alzheimer disease (Asthana et al., 1996; Herz, Fraling, Niedner, \& Färber, 1967; Sullivan, Andres, Otto, Miles, \& Kydd, 2007). But still its toxic effects on the central nervous system are warranted. In our study, it showed the toxic effects in the third instar larvae of transgenic Drosophila melanogaster (hsp70-lacZ) $\mathrm{Bg}^{9}$ (Shakya 
\& Siddique, 2018). The study performed by Shih et al. (2010) on the cultured rat primary cortical neurons showed that it is potent in inducing apoptotic death by attenuating an antioxidant defence system and enhancing the oxidative stress. Arecoline at the concentration of about $0.1-97.39 \mu \mathrm{g} / \mathrm{ml}$ showed to induce reactive oxygen species (ROS) inflammation and oral carcinogenesis (Chang et al., 2004; Jeng et al., 2003; Shih et al., 2010). Hence, we decided to study the effect of arecoline on the adult D. melanogaster (Oregon R).

\section{Materials and methods}

\section{D. melanogaster stock, culture and treatments}

D. melanogaster (Oregon R) was obtained from Drosophila Genetic Resource Centre (DGRC), Kyoto Institute of Technology, Kyoto Stock Centre, Japan. The flies were cultured on the standard Drosophila food containing agar, corn meal, sugar and yeast at $25{ }^{\circ} \mathrm{C}$ (Siddique, Ara, Jyoti, Naz, \& Afzal, 2011; Siddique, Jyoti, \& Naz, 2014). Arecoline hydrobromide (Sigma, USA) was dissolved in distilled water and mixed in the diet to obtain the final concentrations of 5,10,20, 40 and $80 \mu \mathrm{M}$. Newly eclosed 1 to 3 -day-old male flies were starved for $16 \mathrm{~h}$ and then placed on the diet having the desired concentration of arecoline. The flies were allowed to feed on it for 5 days ( 50 flies per vial; 5 replicates/treatment). Methyl methanesulphonate $(10 \mu \mathrm{l} / \mathrm{ml})$ was used as a positive control.

\section{Climbing assay}

The climbing assay was performed as described by Pendleton, Parvez, Sayed, and Hillman (2002). Ten flies were placed in an empty glass vial $(10.5 \mathrm{~cm} \times 2.5 \mathrm{~cm})$. A horizontal line was drawn $8 \mathrm{~cm}$ above the bottom of the vial. After the flies had acclimated for $10 \mathrm{~min}$ at room temperature, both controls and treated groups were assayed at random to a total of 10 trials for each. The flies were then gently tapped down to bottom of the vials. The numbers of flies above the mark of the vial were counted after $10 \mathrm{~s}$ of climbing and repeated 10 times to get the mean number.

\section{Activity pattern}

The activity of newly eclosed starved male flies was analysed by using a Drosophila activity monitor (DAM) (TriTek, USA). The male flies were allowed to feed on the diet having the desired concentration of arecoline. The activity was recorded every $60 \mathrm{~min}$ for a total of 5 days and the data obtained was analysed by Actogram J Software. The results were presented as chi-square periodogram (Chiu, Low, Pike, Yildirim, \& Edery, 2010; Rosato \& Kyriacou, 2006).

\section{Preparation of homogenate for biochemical assays}

At the end of the treatment period, the heads of male flies (50 heads/treatment; 5 replicates/group) were collected, weighted and homogenised in $0.1 \mathrm{M}$ phosphate buffer $(\mathrm{pH}$ 7.4) and centrifuged at $4{ }^{\circ} \mathrm{C}$ at $6000 \mathrm{rpm}$ for $10 \mathrm{~min}$. Subsequently, the supernatant was separated from the pellet into an Eppendorf tube kept in ice, and used for the determination of glutathione (GSH), glutathione-S-transferase (GST), lipid peroxidation assay (LPO), protein carbonyl content (PCC), monoamine oxidase (MAO), caspase-9, caspase-3 and acetylcholinesterase (AChE) activities.

\section{Estimation of glutathione (GSH) content}

The glutathione (GSH) content was estimated colorimetrically using Ellman's reagent (DTNB) according to the procedure described by Jollow, Mitchell, Zampaglione, and Gillette (1974). The supernatant was precipitated with $4 \%$ sulphosalicyclic acid $(4 \times)$ in the ratio of 1:1. The samples were kept at $4{ }^{\circ} \mathrm{C}$ for $1 \mathrm{~h}$ and then subjected to centrifugation at $5000 \mathrm{rpm}$ for $10 \mathrm{~min}$ at $4{ }^{\circ} \mathrm{C}$. The assay mixture consisted of $550 \mu \mathrm{l}$ of $0.1 \mathrm{M}$ phosphate buffer, $100 \mu \mathrm{l}$ of supernatant and $100 \mu \mathrm{l}$ of DTNB. The OD was read at $412 \mathrm{~nm}$ and the results were expressed as micromoles of GSH per gram tissue.

\section{Determination of glutathione-S-transferase (GST) activity}

The glutathione-S-transferase activity was determined by the method of Habig et al. (1974). The reaction mixture consists of $500 \mu \mathrm{l}$ of $0.1 \mathrm{M}$ phosphate buffer, $150 \mu \mathrm{l}$ of $10 \mathrm{mM}$ 1-chloro-2-4, dinitrobenzene (CDNB), $200 \mu \mathrm{l}$ of $10 \mathrm{mM}$ reduced glutathione and $50 \mu \mathrm{l}$ of supernatant. The OD was taken at $340 \mathrm{~nm}$ and the enzyme activity was expressed as micromoles of CDNB conjugates per minute per milligram per protein.

\section{Lipid peroxidation assay (LPO)}

Lipid peroxidation was measured according to the method described by Ohkawa, Ohishi, and Yagi (1978). The reaction mixture consisted of $5 \mu \mathrm{l}$ of $10 \mathrm{mM}$ butyl-hydroxy toluene (BHT), $200 \mu \mathrm{l}$ of $0.67 \%$ thiobarbituric acid, $600 \mu \mathrm{l}$ of $1 \%$ O-phosphoric acid, $105 \mu \mathrm{l}$ of distilled water and $90 \mu \mathrm{l}$ of supernatant. The resultant mixture was incubated at $90{ }^{\circ} \mathrm{C}$ for $45 \mathrm{~min}$ and the OD was measured at $535 \mathrm{~nm}$. The results were expressed as micromoles of TBARS formed per hour per gram tissue.

\section{Estimation of protein carbonyl content (PCC)}

The protein carbonyl content was estimated according to the protocol described by Hawkins, Morgan, and Davies (2009). The brain homogenate was diluted to a protein concentration of approximately $1 \mathrm{mg} / \mathrm{ml}$. About $250 \mu \mathrm{l}$ of each diluted homogenate was taken in Eppendorf centrifuge tubes separately. To it $250 \mu \mathrm{l}$ of $10 \mathrm{mM}$ 2,4-dinitrophenyl hydrazine (dissolved in $2.5 \mathrm{M} \mathrm{HCl}$ ) was added, 
vortexed and kept in dark for $20 \mathrm{~min}$. About $125 \mu \mathrm{l}$ of $50 \%(w / v)$ trichloroacetic acid (TCA) was added, mixed thoroughly and incubated at $-20^{\circ} \mathrm{C}$ for $15 \mathrm{~min}$. The tubes were then centrifuged at $4{ }^{\circ} \mathrm{C}$ for $10 \mathrm{~min}$ at $9000 \mathrm{rpm}$. The supernatant was discarded and the pellet obtained was washed twice by ice cold ethanol: ethyl acetate (1:1). Finally, the pellets were re-dissolved in $1 \mathrm{ml}$ of $6 \mathrm{M}$ guanidine hydrochloride and the absorbance was read at $370 \mathrm{~nm}$.

\section{Determination of acetylcholinesterase (AchE) activity}

Acetylcholinesterase activity was estimated according to the method of Ellman, Courtney, Andres Jr, and Featherstone (1961). The reaction mixture consisted of $650 \mu \mathrm{l}$ of $0.1 \mathrm{M}$ phosphate buffer (pH 7.4), $100 \mu \mathrm{l}$ of $10 \mathrm{mM}$ 5,5'-dithiobis-2-nitrobenzoic acid (DTNB) and $100 \mu \mathrm{l}$ of supernatant. The content was mixed thoroughly and the absorbance was measured at $412 \mathrm{~nm}$. After having a stable absorbance value, $10 \mu \mathrm{l}$ of $0.075 \mathrm{M}$ acetylthiocholine was added and the change in absorbance per minute was recorded, to calculate the enzyme activity.

\section{Estimation of monoamine oxidase (MAO)}

The method described by McEwan (1965) was used to estimate the monoamine oxidase activity. The assay mixture consisted of $400 \mu \mathrm{l}$ of 0.1.M phosphate buffer ( $\mathrm{pH}$ 7.4.), $1300 \mu \mathrm{l}$ of distilled water, $100 \mu \mathrm{l}$ of benzylamine hydrochloride and $200 \mu \mathrm{l}$ of brain homogenate. The assay mixture was incubated for $30 \mathrm{~min}$ at room temperature and then $1 \mathrm{ml}$ of $10 \%$ perchloric acid was added and centrifuged at $1500 \mathrm{~g}$ for $10 \mathrm{~min}$. The OD was taken at $280 \mathrm{~nm}$.

\section{Spectrophotometric assay for caspase-9 (Dronc) and caspase-3 (Drice) activities}

The assay was performed according to the manufacturer protocol with some modification (Bio-Vision, CA, USA). The assay was based on spectrophotometric detection of the chromophore p-nitroanilide (pNA) obtained after specific action of caspase-3 and caspase- 9 on tetrapeptide substrates, DEVD-pNA and IETD-pNA, respectively. The assay mixture consisted of $50 \mu \mathrm{l}$ of fly head homogenate and $50 \mu \mathrm{l}$ of chilled cell lysis buffer incubated on ice for $10 \mathrm{~min}$. After incubation, $50 \mu \mathrm{l}$ of $2 \times$ reaction buffer (containing $10 \mathrm{mM}$ DTT) with $200 \mu \mathrm{M}$ substrate (DEVD-pNA for Drice, and IETD-pNA for Dronc) was added and incubated at $37^{\circ} \mathrm{C}$ for $1.5 \mathrm{~h}$. The reaction was quantified at $405 \mathrm{~nm}$.

\section{Apoptotic index (Al)}

After isolating the brains (20/treatment; 5 replicates per group) in PBS from treated and control group, the brain cell suspension was prepared by exposing the isolated brain to collagenase $(0.5 \mathrm{mg} / \mathrm{ml})$ for $2 \mathrm{~min}$. The cells were centrifuged to remove cellular debris and the suspended cells were incubated in a cocktail of acridine orange $(1 \mu \mathrm{g} / \mathrm{ml})$ and ethidium bromide $(1 \mu \mathrm{g} / \mathrm{ml})$ for $3 \mathrm{~min}$. The cells were washed with PBS and observed under a fluorescent microscope. For the quantification of extent of apoptosis, a total of 100 cells were scored. The live cells appeared green, apoptotic cells appeared orange and necrotic cells red (Singla \& Dhawan, 2013).

\section{Effect of pupation and emergence of flies}

To study the effect of arecoline on the pupation and emergence of flies, the arecoline was mixed in diet at a final concentration of $5,10,20,40$ and $80 \mu \mathrm{M}$. To these doses, 50 first instar larvae were introduced. Triplicate sets of each treatment group (including the untreated and positive control) were employed in the study. Each day the numbers of larvae pupate followed by number of flies emergence were recorded separately and the data was expressed as mean of three replicates (Podder and Roy, 2014).

\section{Drosophila life span determination}

Newly eclosed flies were placed in the culture tubes (10 flies per tube) containing desired concentration of the arecoline. The flies were transferred to a new diet at every third day containing desired concentration of the arecoline till the last one died (Long, Gao, Sun, Liu, \& Zhao-Wilson, 2009).

\section{Phenotypic analysis of eye}

The newly emerged flies, from the larvae which were allowed to feed on the 5, 10, 20, 40 and $80 \mu \mathrm{M}$ of arecoline, were analysed for the phenotypic anomaly in eyes. The heads (20 heads/treatment; 5 replicates/group) were collected in PBS, and the eye caps were separated and stained by $1 \%$ toluidine blue for 2 min and observed for any deformity in the ommatidia under a light microscope.

\section{Statistical analysis}

All data were expressed as mean \pm standard error, and Dunnet ANOVA test was used for the analysis by using software SPSS 16. Statistical significance was considered at the $5 \%$ level.

\section{Results}

The results obtained for the climbing ability showed a dose-dependent significant loss of 1.43, 1.76 and 2.13 folds in the flies exposed to 20,40 and $80 \mu \mathrm{M}$ of arecoline, respectively, compared to control (Fig. 1; $p<0.05$ ). The flies exposed to 5 and $10 \mu \mathrm{M}$ of arecoline did not show any loss in the climbing ability compared to control (Fig. $1 ; p<0.05$ ). The positive control was associated with the fourfold decrease in the climbing ability compared to control (Fig. $1 ; p<0.05$ ). The results obtained for activity pattern (Additional file 1: Figures S1-S7) showed a dose-dependent loss in the activity of flies exposed to 20,40 and $80 \mu \mathrm{M}$ of arecoline compared to 


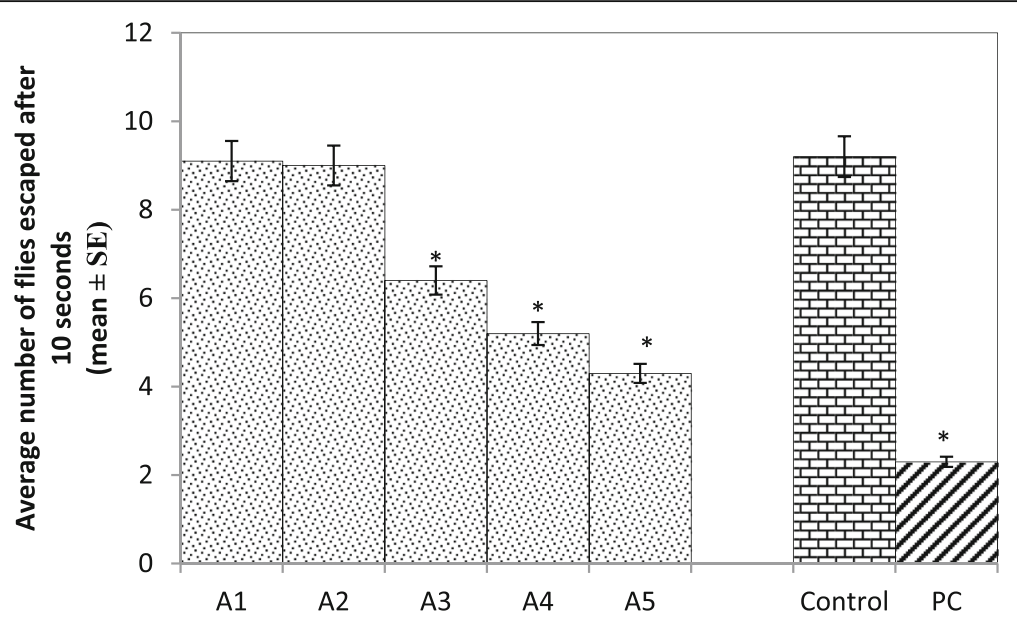

Fig. 1 Climbing assay performed on flies exposed to various doses of arecoline ( $\mathrm{A} 1=5 \mu \mathrm{M}$ arecoline, $\mathrm{A} 2=10 \mu \mathrm{M}$ arecoline, $\mathrm{A} 3=20 \mu \mathrm{M}$ arecoline, $\mathrm{A} 4=40 \mu \mathrm{M}$ arecoline, $\mathrm{A} 5=80 \mu \mathrm{M}$ arecoline, $\mathrm{PC}=10 \mu \mathrm{l} / \mathrm{ml}$ methyl methanesulphonate), ${ }^{*}$ significant at $p<0.05$ compared to control

control flies (Additional file 1: Figures S3-S5). The flies exposed to 5 to $10 \mu \mathrm{M}$ of arecoline did not show any change in the activity pattern as is clearly evident from peaks near the midline compared to control (Additional file 1: Figures S1-S2). The result obtained for GSH content showed that the flies exposed to 5 and $10 \mu \mathrm{M}$ of arecoline did not show any significant decrease in the GSH content compared to control flies. The flies exposed to 20, 40 and $80 \mu \mathrm{M}$ of arecoline showed a significant dose-dependent decrease of 1.29, 1.40 and 1.52 folds compared to control flies (Fig. 2a; $p<0.05$ ). The flies exposed to 5 and $10 \mu \mathrm{M}$ of arecoline did not show any significant increase in the activity of GST compared to control flies (Fig. $2 \mathrm{~b} ; p<0.05$ ). The flies exposed to 20,40 and $80 \mu \mathrm{M}$ of arecoline showed a significant dose-dependent increase of 1.60, 1.76 and 1.85 folds in the GST activity compared to control flies (Fig. 2b; $p<$ $0.05)$. The flies exposed to 5 and $10 \mu \mathrm{M}$ of arecoline did not show any significant increase in LPO compared to control flies (Fig. 2c; $p<0.05$ ). The flies exposed to 20, 40 and $80 \mu \mathrm{M}$ of arecoline showed a significant dose-dependent increase of 2.37, 2.87 and 3.62 folds in LPO as compared to control flies (Fig. 2c; $p<0.05$ ). The flies exposed to 5 and $10 \mu \mathrm{M}$ of arecoline did not show any significant increase in protein carbonyl content (PCC) as compared to control flies (Fig. 2d; $p<0.05$ ). The flies exposed to 20,40 and $80 \mu \mathrm{M}$ of arecoline showed a significant increase of $2.77,3.83$ and 4.17 folds, respectively, compared to control flies (Fig. $2 \mathrm{~d} ; p<0.05$ ). The flies exposed to 5 and $10 \mu \mathrm{M}$ of arecoline did not show any significant decrease in the activity of acetylcholinesterase (AchE) in the brains of flies as compared to control (Fig. 3a; $p<0.05$ ). The flies exposed to 20, 40 and $80 \mu \mathrm{M}$ of arecoline showed a dose-dependent significant decrease of $1.68,1.94$ and 2.38 folds respectively as compared to control flies (Fig. 3a; $p<0.05$ ). The results obtained for MAO activity showed no increase compared to control flies in the brain of flies exposed to 5 and $10 \mu \mathrm{M}$ of arecoline (Fig. 3b; $p<0.05$ ). The flies exposed to 20,40 and $80 \mu \mathrm{M}$ of arecoline showed a significant dose-dependent increase of 1.61, 2.16 and 2.51 folds respectively in the activity of MAO compared to control flies (Fig. 3b; $p<0.05)$. Figure $4(\mathrm{~A} 1-\mathrm{A} 5)$ shows apoptotic cells in the brain of flies exposed to various doses of arecoline. A dose-dependent increase in the apoptotic cells was observed in the brain of flies exposed to 20,40 and $80 \mu \mathrm{M}$ of arecoline (Fig. 4, A3-A5) compared to control (Fig. 4c). The exposure of flies to 20, 40 and $80 \mu \mathrm{M}$ of arecoline showed a dose-dependent increase of $2.57,3.28$ and 3.71 folds in the activity of caspase- 3 respectively as compared to control (Fig. $5 \mathrm{a} ; p$ $<0.05)$. The flies exposed to 5 and $10 \mu \mathrm{M}$ of arecoline did not show any increase in the activity of caspase- 3 (Fig. 5a; $p<0.05$ ). Similarly for caspase-9, the flies exposed to 20, 40 and $80 \mu \mathrm{M}$ of arecoline showed a dose-dependent significant increase of 1.81, 2.31 and 2.87 folds, respectively, compared to control (Fig. 5b; $p$ $<0.05$ ). The exposed flies to 5 and $10 \mu \mathrm{M}$ of arecoline did not show any increase in the activity of caspase-9 (Fig. 5b; $p<0.05$ ). The exposure of 5 and $10 \mu \mathrm{M}$ of arecoline did not show any significant increase in apoptotic index (Fig. 5c). The exposure of 20, 40 and $80 \mu \mathrm{M}$ of arecoline to the flies showed a dose-dependent significant increase of 3.31, 5.42 and 8.52 folds in the apoptotic index compared to control (Fig. $5 \mathrm{c} ; p<0.05$ ).

The results obtained for the pupation of larvae showed no significant change in the rate of pupation in the larvae exposed to 5 and $10 \mu \mathrm{M}$ of arecoline compared to control (Fig. 6a; $p<0.05$ ). The larvae exposed to 20,40 and $80 \mu \mathrm{M}$ of arecoline showed a significant dose-dependent delay in the rate of pupation compared to control (Fig. 6a; $p<0.05$ ). The results obtained for the 


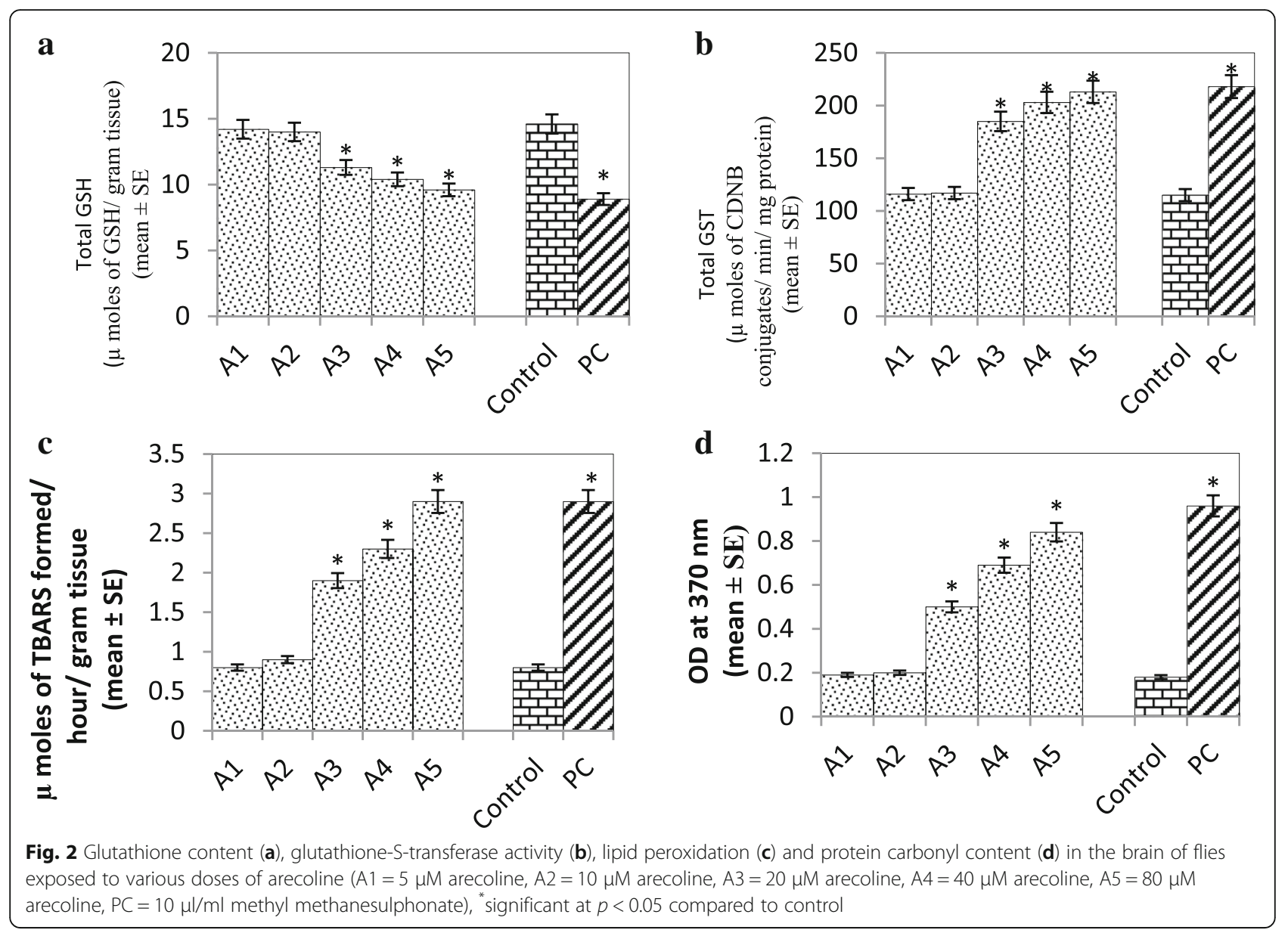

emergence of flies showed no significant change at the doses of 5 and $10 \mu \mathrm{M}$ of arecoline compared to control (Fig. 6b; $p<0.0 .5$ ). The pupa formed from the larvae exposed to 20,40 and $80 \mu \mathrm{M}$ of arecoline showed a dose-dependent significant delay in the emergence of flies compared to control (Fig. 6b; $p<0.05$ ). The result obtained for the survival assay is shown in Fig. 6c. No significant change in the life span of the flies exposed to 5 and $10 \mu \mathrm{M}$ of arecoline was observed compared to control flies (Fig. 6c; $p<0.05$ ). The flies exposed to 20, 40 and $80 \mu \mathrm{M}$ of arecoline showed a dose-dependent decrease in the survival rate compared to control flies (Fig. 6c; $p<0.05$ ). The flies emerged from the larvae exposed to 5 and $10 \mu \mathrm{M}$ of arecoline did not show any deformity in eyes. Each ommatidium was uniform and exhibits a normal hexagonal arrangement. There were regular polarised inter ommatidial bristles (Fig. 7, A1, A2). However the flies emerged from the larvae exposed to 20,40 and $80 \mu \mathrm{M}$ of arecoline showed dose dependent deformities in the eyes. Ommatidia were round, inter-ommatidial bristles were disoriented and of variable length (Fig. 7, A3-A5). At highest dose the inter-ommatidial bristles were absent and the ommatidia clearly exhibited the round texture (Fig. 7, A5). The hexagonal arrangement was lost in a dose dependent manner as compared to control (Fig. 7, c).

\section{Discussion}

The results of the present study reveal that arecoline is toxic at 20,40 and $80 \mu \mathrm{M}$. In our present study, the exposure of flies to 20,40 and $80 \mu \mathrm{M}$ showed a dose-dependent significant decrease in the climbing ability of flies. This may be due to the disruption of the coordination between the nervous system and muscular activity. Such impairment has also been observed in the flies exposed to pesticides, mainly organophosphates (Rajak, Dutta, Khatun, Mandi, \& Roy, 2017) and 4-vinylcyclohexane (Abolaji et al., 2014). Similarly, the flies exposed to 20,40 and $80 \mu \mathrm{M}$ of arecoline showed a dose-dependent reduction in the overall activity as is evident from the activity pattern. However, arecoline has also been reported to improve cognitive performance in Alzheimer's disease (Raffaele et al., 1996). Hence, it becomes important to explore its effects on the cognitive ability and the oxidative stress markers. Arecoline showed neurotoxic effects through increase in reactive 

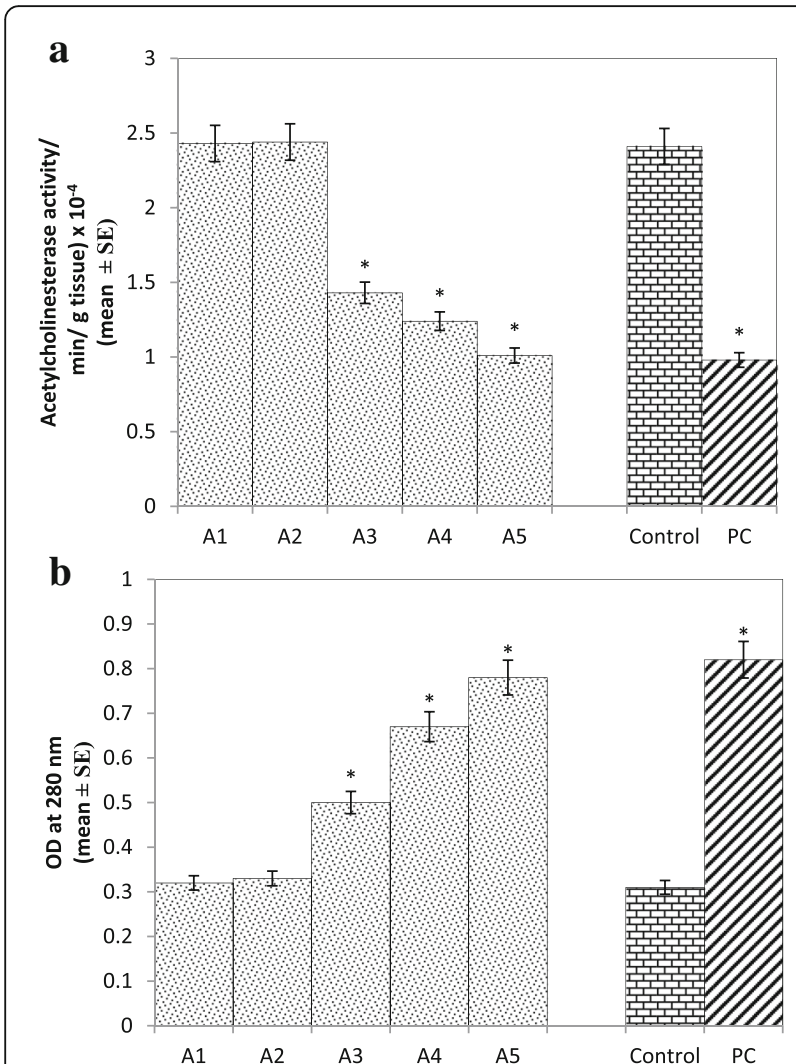

Fig. 3 Acetycholineesterase (a) and monoamine oxidase (b) activities measured in flies exposed to various doses of arecoline ( $\mathrm{A} 1=5 \mu \mathrm{M}$ arecoline, $\mathrm{A} 2=10 \mu \mathrm{M}$ arecoline, $\mathrm{A} 3=20 \mu \mathrm{M}$ arecoline, $\mathrm{A} 4=40 \mu \mathrm{M}$ arecoline, $\mathrm{A} 5=80 \mu \mathrm{M}$ arecoline, $\mathrm{PC}=10 \mu \mathrm{l} / \mathrm{ml}$ methyl methanesulphonate), ${ }^{*}$ significant at $p<0.05$ compared to control

oxygen species (ROS). It also decrease antioxidants levels (Shih et al., 2010). The results obtained in our present study supports the results of Shih et al. (2010) as the flies exposed to higher doses of arecoline showed a decline in the climbing ability as well as in the overall activity of the flies. GSH is a most abundant thiol present in the eukaryotic cells. Arecoline react with free thiols such as GSH and $N$-acetyl-cysteine (NAC) to produce a common cysteine. $\beta$-alkylation adduct losing the methyl ester group present in neural aqueous solution, hence leading to the depletion of the GSH content (Boyland \& Nery, 1969). Thus, depletion in the levels of GSH leads to cytotoxicity (Jeng et al., 1999). In our study, also the low levels of GSH were observed in the flies exposed to 20,40 and $80 \mu \mathrm{M}$ of arecoline. GST takes part in adding $-\mathrm{SH}$ group to the phase I metabolised products for its proper excretion. The elevated levels of GST at higher doses of arecoline are a clear indication of the detoxification process. Reactive oxidants are generated continuously in biological systems via both endogenous processes and a result of exposure to external factors such as drugs, chemicals and pollutants (Hawkins et al.,

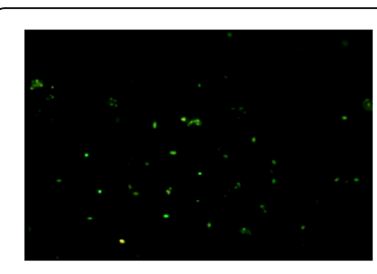

A1

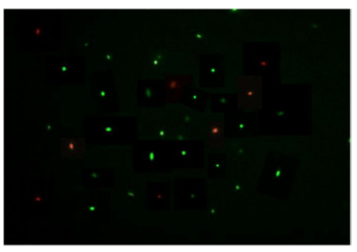

A3

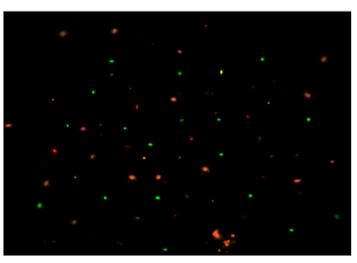

A5

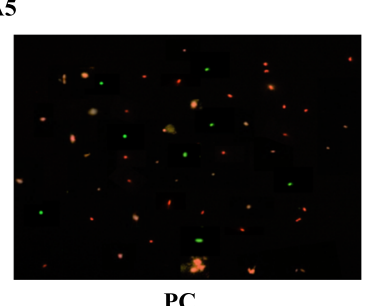

PC

Fig. 4 Fluorescent staining of brain cells with acridine orange and ethidium bromide dye in the different groups visualised under the fluorescent microscope, $(\mathrm{A} 1=5 \mu \mathrm{M}$ arecoline, $\mathrm{A} 2=10 \mu \mathrm{M}$ arecoline, $\mathrm{A} 3=20 \mu \mathrm{M}$ arecoline, $\mathrm{A} 4=40 \mu \mathrm{M}$ arecoline, $\mathrm{A} 5=80 \mu \mathrm{M}$ arecoline, $\mathrm{C}$ $=$ Control, $\mathrm{PC}$ (Positive Control) $=10 \mu \mathrm{l} / \mathrm{ml}$

methyl methanesulphonate)

2009). Damage has been reported to occur on all components of biological systems due to high reactivity of many oxidants. Proteins and lipids are likely to be major targets due to their abundance in the living system. The metabolic activation of arecoline has been reported to generate reactive oxygen species (ROS) (Giri et al., 2006). This ROS may lead to the oxidation of protein and lipid membrane resulting in the carboxylation of protein and malondialdehyde (MDA) (a key product of LPO), respectively. Thus, increase in the PC content as well as MDA in the flies exposed to higher doses of arecoline supports the generation of ROS at higher doses of arecoline leading to oxidative stress. The activity of acetylcholinesterase (AchE) showed a decrease at the exposure of higher doses of arecoline. AchE hydrolyses the neurotransmitter acetylcholine to terminate the synaptic transmission. Any decrease in the AchE is a good marker for neural pathology. There are also reports of an increase in AchE activity upon the exposure of 

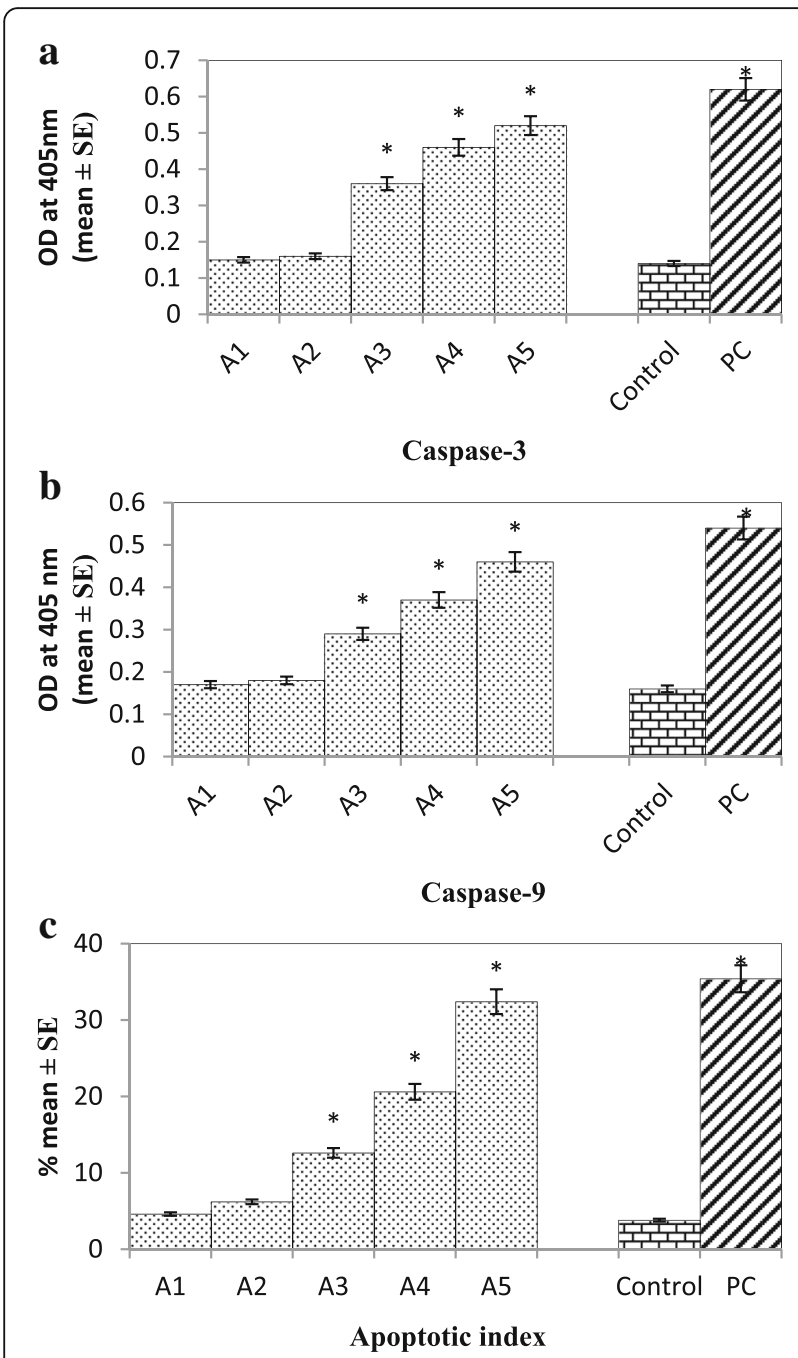

Fig. 5 Activity of caspase-3 (a), caspase-9 (b) and apoptotic index (c), measured in the brain cells of the flies exposed to various doses of arecoline. Arecoline (A1 $=5 \mu \mathrm{M}$ arecoline, $\mathrm{A} 2=10 \mu \mathrm{M}$ arecoline, $\mathrm{A} 3=20 \mu \mathrm{M}$ arecoline, $\mathrm{A} 4=40 \mu \mathrm{M}$ arecoline, $\mathrm{A} 5=80 \mu \mathrm{M}$ arecoline, $\mathrm{PC}=10 \mu \mathrm{l} / \mathrm{ml}$ methyl methanesulphonate), ${ }^{*}$ significant at $p<0.05$ compared to control

arecoline (Jeng et al., 1999), but a decrease in AchE activity has also been reported in the brain ganglia of the Drosophila larvae that were temperature shocked and exposed to certain chemicals at higher concentrations (Mukhopadhyay, Saxena, \& Chowdhuri, 2003). According to cholinergic hypothesis, reduction of acetylcholine is responsible for the development of Alzheimer's diseases (AD) (Kumar \& Singh, 2015). Inhibition of acetylcholinesterase could be a better strategy in improving the cognitive defects among AD patients (Holden \& Kelly, 2002). In our study, although the exposure of arecoline results in a significant dose-dependent decrease in the activity of acetylcholinesterase, the activity of flies as measured by Drosophila activity monitor (DAM) as well as the climbing ability showed a marked decline. Monoamine oxidase is an iron containing enzyme that catalyses bioactive monoamines (Richardson, 1993). It has also been reported to maintain the neuron firing rate and is involved in the metabolism of dopamine. The metabolism of dopamine could also lead to the generation of ROS that could further enhance the neuronal damage. The reduction in the climbing ability as well as the reduced activity of flies exposed to higher doses of arecoline could be due to the enhanced metabolism of dopamine by MAO because the dopamine is a main component involved in neuromuscular coordination (Mazzoni, Shabbott, \& Cortés, 2012). Although the mammalian system of cytochromes may be entirely different from the insect system, the basic function of the cytochromes may have similarity in the mode of action. Midgut tissues of insects have high microsomal oxidase activity (Giri et al., 2006). Caspases, a group of cysteine proteases, constitute the effector arm of the cell death machinery. The genome sequence of $D$. melanogaster predicts a total of seven caspases in flies (Kumar \& Doumanis, 2000). A comparison of the amino acid sequences of fly and mammalian caspases reveals the evolutionary relationship between caspases. In a mammalian system, the release of cytochrome $\mathrm{c}$ into the cytoplasm leads to the decrease in the $\mathrm{Bcl}-2$ activity. The decrease in the Bcl-2 activity enhanced proapoptotic Bax levels which finally initiates apoptosis by activating caspase-3 activity (Singla \& Dhawan, 2013). However, there are conflicting reports of cytochrome $\mathrm{C}$ release from the mitochondria of Drosophila cells during apoptosis (Kumar \& Doumanis, 2000). Due to the exposure to various toxicants, the increase in the activity of caspase- 9 (Dronc) and caspase-3(Drice) has been reported earlier (Singh \& Chowdhuri, 2017; Danish et al., 2015; Pandey, Chandra, Chauhan, Narayan, \& Chowdhuri, 2013). In our study, the exposure of arecoline results in an increase in the activity of caspase- 3 and caspase-9. Further, acridine orange and ethidium bromide staining also revealed an increase in the number of apoptotic neuronal cells (orange coloured due to ethidium bromide stain) as compared to green neuronal cells (acridine orange stained). A dose-dependent significant increase in the apoptotic index also supports that the exposure of arecoline increases the number of apoptotic cells. The increase in the number of apoptotic cells is likely due to nuclear fragmentation, cell shrinkage and nuclear condensation in neuronal cells (Singla \& Dhawan, 2013). A dose-dependent increase in the apoptotic cells was observed in the brain cells of flies exposed to 20, 40 and $80 \mu \mathrm{M}$ of arecoline.

In the present study, arecoline hydrobromide was used for the first time to study whether its exposure was associated with toxic effects using D. melanogaster as a model. It has been reported that about $75 \%$ of human disease-causing genes have functional homology in $D$. 

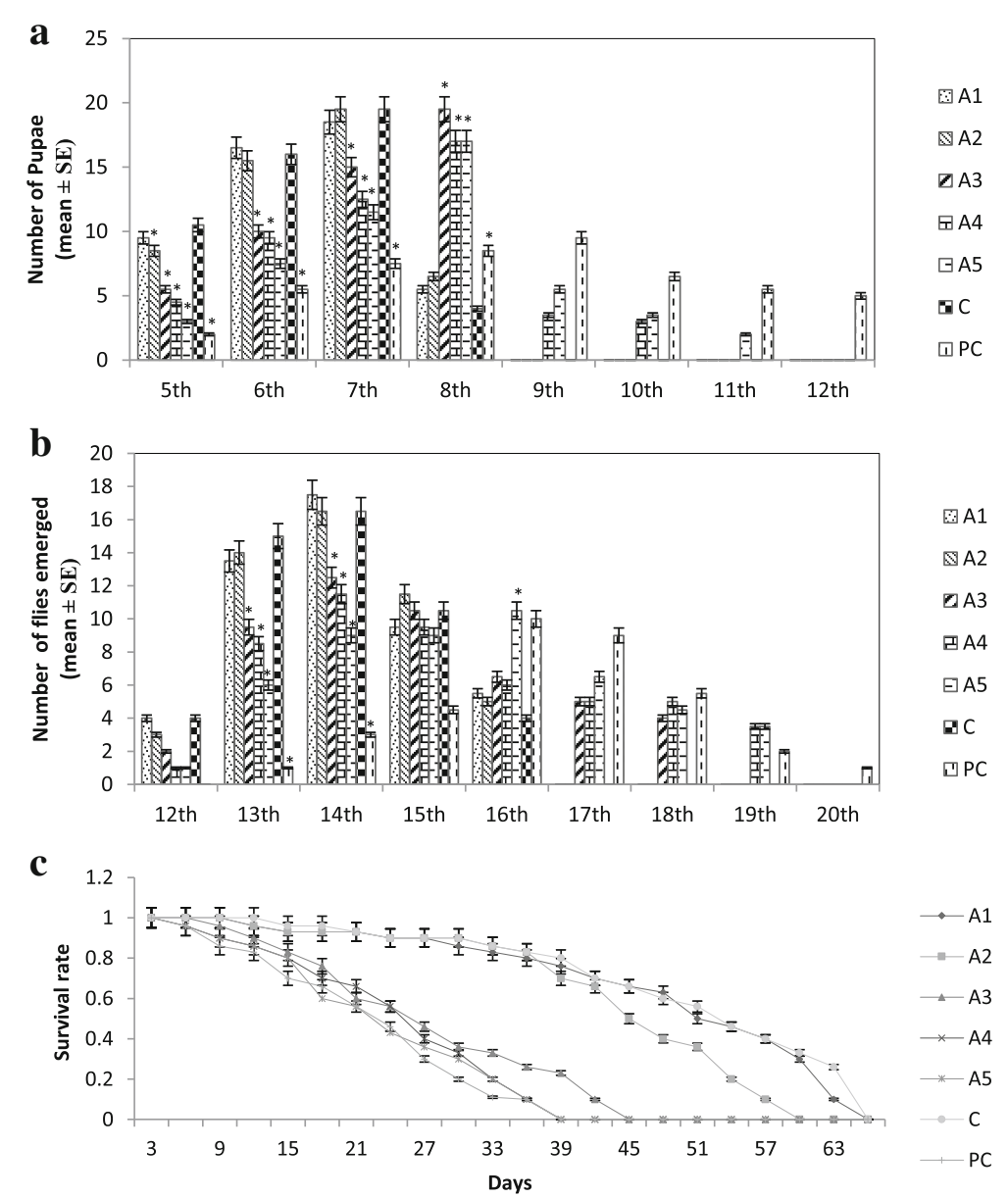

Fig. 6 Effect on the pupation (a), emergence $(\mathbf{b})$ and life span (c) of the flies after the exposure to various doses of arecoline $(A 1=5 \mu M$ arecoline, $\mathrm{A} 2=10 \mu \mathrm{M}$ arecoline, $\mathrm{A} 3=20 \mu \mathrm{M}$ arecoline, $\mathrm{A} 4=40 \mu \mathrm{M}$ arecoline, $\mathrm{A} 5=80 \mu \mathrm{M}$ arecoline, $\mathrm{PC}=10 \mu \mathrm{l} / \mathrm{ml}$ methyl methanesulphonate), ${ }^{*}$ significant at $p<0.05$ compared to control

melanogaster, and therefore, it is being used as a model for toxicological studies (Rand, 2010). Further, we also investigated the effect of arecoline hydrobromide on pupation and emergence of flies. A significant dosedependent increase in the duration of pupation was observed at 20, 40 and $80 \mu \mathrm{M}$ of arecoline and lower doses fail to express any dose-dependent increase in the duration of pupation. This delay in the pupation of larvae at higher doses may be due to the activation of some drug metabolising enzymes (Pai, 1983; Podder \& Roy, 2015). Similarly, the emergence of the flies was also significantly delayed in a dose-dependent manner compared to the control flies. Similar results have been obtained by the treatments of cryolite and fluorinated insecticide (Podder \& Roy, 2015. Gupta, Siddique, Saxena, \& Chowdhuri, 2005). The delay in the emergence of flies is possible due to the activation of enzymes involved in the detoxification of the drug during the pupation. Besides these effects, arecoline has also been shown to induce various kinds of genetic damages, such as chromosomal aberrations, sister chromatid exchange, DNA breaks and DNA protein cross-links on different target cells (Jeng, Chang, \& Hahn, 2001). Arecoline also exhibits cytotoxicity and inhibits the growth of oral fibroblasts and keratinocytes (Chang et al., 1998; Tseng et al., 2012). The eyes of emerged flies were also analysed for the phenotypic abnormalities. Clear dose-dependent deformities were observed in the flies emerged from the exposure of larvae to 20,40 and $80 \mu \mathrm{M}$ of arecoline. The flies showed the loss of hexagonal texture in a dose-dependent manner, bristles were also lost and the ommatidia were of round shape. The studies on insecticides and pesticides have revealed well-defined effects on the life cycle, hatching ability and the emergence of D. melanogaster (Gupta et al., 2005; Podder \& Roy, 2015). The exposure of arecoline not only increased the duration of pupation but also delayed the emergence of flies. It also decreased the life span of flies exposed to 20,40 and $80 \mu \mathrm{M}$ of arecoline in a dose-dependent manner. 


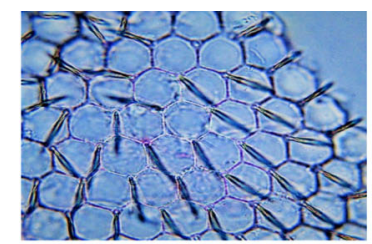

A1

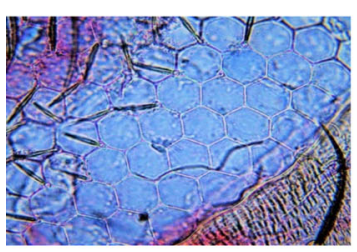

A3

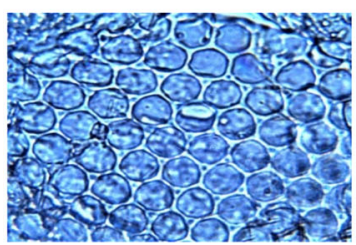

A5

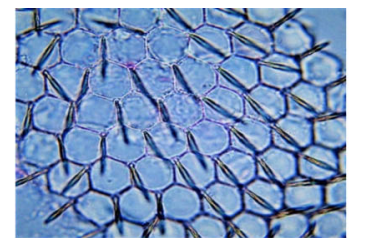

A2

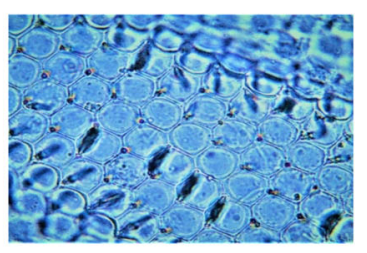

A4

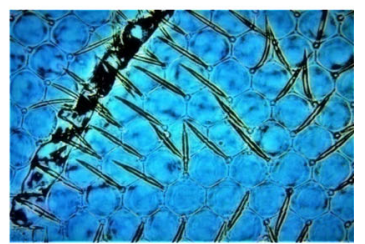

C

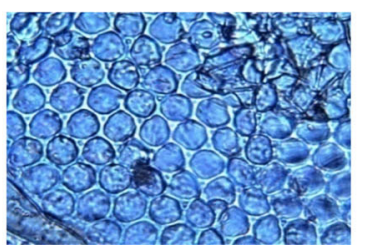

PC

Fig. 7 Eye surface of the emerged flies from the larvae exposed to various doses of arecoline, $(\mathrm{A} 1=5 \mu \mathrm{M}$ arecoline, $\mathrm{A} 2=10 \mu \mathrm{M}$ arecoline, $\mathrm{A} 3=20 \mu \mathrm{M}$ arecoline, $\mathrm{A} 4=40 \mu \mathrm{M}$ arecoline, $\mathrm{A} 5=80 \mu \mathrm{M}$ arecoline, $C=$ Control, $P C$ (Positive Control) $=10 \mu \mathrm{l} / \mathrm{ml}$ methyl methanesulphonate)

This reduction is due to the neuronal damage which may be due to the exposure to arecoline. Betel chewers typically achieve salivary concentrations of arecoline ranging from 40 to $400 \mu \mathrm{M}$ and $90 \%$ of betel chewers have a residual level of at least $400 \mathrm{nM}$ prior to chewing (Cox, Vickers, Ghu, \& Zoellner, 2010; Papke, Horenstein, \& Stokes, 2015). It has been suggested that arecoline would not be a good candidate for further development in the direction of therapeutic potential due to its strong muscarinic activity and potential involvement in the carcinogenesis (Papke et al., 2015). Arecoline at concentration above $50 \mu \mathrm{M}$ has been shown to cause neuronal injury by causing an increase in oxidative stress and suppression of the anti-oxidant system of the nervous system. A higher concentration may also lead to the cell death (Shih et al., 2010).

\section{Conclusion}

It is concluded from the results obtained in our study that arecoline not only is a neurotoxic agent but also affects the life cycle parameters of the fly.

\section{Additional file}

Additional file 1: Figure S1. $a$ and $b$ showing the average activity pattern and chi square periodogram, respectively for the flies exposed to $5 \mu \mathrm{M}$ of arecoline. Figure $\mathbf{S 2}$. $\mathrm{a}$ and $\mathrm{b}$ showing the average activity pattern and chi square periodogram, respectively for the flies exposed to $10 \mu \mathrm{M}$ of arecoline. Figure S3. $\mathrm{a}$ and $\mathrm{b}$ showing the average activity pattern and chi square periodogram, respectively for the flies exposed to $20 \mu \mathrm{M}$ of arecoline. Figure $\mathbf{S 4}$. $\mathrm{a}$ and $\mathrm{b}$ showing the average activity pattern and chi square periodogram, respectively for the flies exposed to $40 \mu \mathrm{M}$ of arecoline. Figure $\mathbf{S 5}$. $\mathrm{a}$ and $\mathrm{b}$ showing the average activity pattern and chi square periodogram, respectively for the flies exposed to $80 \mu \mathrm{M}$ of arecoline. Figure $\mathbf{S 6}$. $\mathrm{a}$ and $\mathrm{b}$ showing the average activity pattern and chi square periodogram, respectively for the control flies. Figure S7. $a$ and $b$ show the average activity pattern and chi square periodogram, respectively for the flies exposed to $10 \mu \mathrm{l} / \mathrm{ml}$ of methyl methanesulfonate. (DOCX $627 \mathrm{~kb}$ )

\section{Abbreviations}

AChE: Acetylcholinesterase; Al: Apoptotic index; BHT: Butyl-hydroxy toluene; CDNB: 1-Chloro-2-4, dinitrobenzene; DAM: Drosophila activity monitor; DNA: Deoxyribonucleic acid; DTNB: 5,5'-Dithiobis-2-nitrobenzoic acid: GSH: Glutathione; GST: Glutathione-S-transferase; HCl: Hydrochloric acid; LPO: Lipid peroxidation assay; MAO: Monoamine oxidase; MDA: Malondialdehyde; NAC: N-Acetyl-cysteine; PBS: Phosphate buffer solution; PCC: Protein carbonyl content; ROS: Reactive oxygen species; TCA: Trichloroacetic acid

\section{Acknowledgements}

We are thankful to the Chairman of the Department of Zoology for providing the Laboratory facilities and UGC for providing non-net fellowship to Ms. Barkha Shakya, Department of Zoology, Faculty of Life Sciences, Aligarh Muslim University, Aligarh, Uttar Pradesh, India. We are also thankful to Dr. Smita Jyoti, Rahul and Falaq Naz for their support and technical help.

\section{Funding}

None

Availability of data and materials Not applicable

\section{Authors' contributions}

YHS wrote the paper and performed experiments. BS performed the experiments and analysed data. Both authors read and approved the final manuscript.

Ethics approval and consent to participate

Not required

Consent for publication

Not applicable

\section{Competing interests}

The authors declare that they have no competing interests.

\section{Publisher's Note}

Springer Nature remains neutral with regard to jurisdictional claims in published maps and institutional affiliations.

Received: 31 May 2018 Accepted: 21 October 2018

Published online: 14 November 2018

\section{References}

Abolaji, A. O., Kamdem, J. P., Lugokenski, T. H., Nascimento, T. K., Waczuk, E. P., Farombi, E. O., ... Rocha, J. B. T. (2014). Involvement of oxidative stress in 4-vinylcyclohexene-induced toxicity in Drosophila melanogaster. Free Radical Biology and Medicine, 71, 99-108. 
Asthana, S., Greig, N. H., Holloway, H. W., Raffaele, K. C., Berardi, A., Schapiro, M. B., .. Soncrant, T. T. (1996). Clinical pharmacokinetics of arecoline in subjects with Alzheimer's disease. Clinical Pharmacology \& Therapeutics, 60(3), 276-282.

Boyland, E., \& Nery, R. (1969). Mercapturic acid formation during the metabolism of arecoline and arecaidine in the rat. Biochemical Journal, 113(1), 123-130.

Chang, M. C., Kuo, M. Y. P., Hahn, L. J., Hsieh, C. C., Lin, S. K., \& Jeng, J. H. (1998). Areca nut extract inhibits the growth, attachment, and matrix protein synthesis of cultured human gingival fibroblasts. Journal of Periodontology, 69(10), 1092-1097.

Chang, M. C., Wu, H. L., Lee, J. J., Lee, P. H., Chang, H. H., Hahn, L. J., ... Jeng, J. H. (2004). The induction of prostaglandin E2 production, interleukin-6 production, cell cycle arrest, and cytotoxicity in primary oral keratinocytes and KB cancer cells by areca nut ingredients is differentially regulated by MEK/ERK activation. Journal of Biological Chemistry, 279(49), 50676-50683.

Chiu, J. C., Low, K. H., Pike, D. H., Yildirim, E., \& Edery, I. (2010). Assaying locomotor activity to study circadian rhythms and sleep parameters in Drosophila. J Vis Exp, (43). https://doi.org/10.3791/2157.

Chou, W. W., Guh, J. Y., Tsai, J. F., Hwang, C. C., Chiou, S. J., \& Chuang, L. Y. (2009). Arecoline-induced phosphorylated p53 and p21WAF1 protein expression is dependent on ATM/ATR and phosphatidylinositol-3-kinase in clone-9 cells. Journal of Cellular Biochemistry, 107(3), 408-417.

Cox, S., Vickers, E. R., Ghu, S., \& Zoellner, H. (2010). Salivary arecoline levels during areca nut chewing in human volunteers. Journal of Oral Pathology \& Medicine, 39(6), 465-469.

Danish, M., Fatima, A., Khanam, S., Jyoti, S., Ali, F., Naz, F., \& Siddique, Y. H. (2015). Evaluation of the toxic potential of calcium carbide in the third instar larvae of transgenic Drosophila melanogaster (hsp70-lacZ) Bg9. Chemosphere, 139, 469-478.

Dasgupta, R., Saha, I., Pal, S., Bhattacharyya, A., Sa, G., Nag, T. C., \& Maiti, B. R. (2006). Immunosuppression, hepatotoxicity and depression of antioxidant status by arecoline in albino mice. Toxicology, 227(1-2), 94-104.

Ellman, G. L., Courtney, K. D., Andres Jr., V., \& Featherstone, R. M. (1961). A new and rapid colorimetric determination of acetylcholinesterase activity. Biochemical Pharmacology, 7(2), 88-95.

Fareed, M., Afzal, M., \& Siddique, Y. H. (2011). Micronucleus investigation in buccal mucosal cells among pan masala/gutkha chewers and its relevance for oral cancer. Biologie et Médecine, 3(2), 8-15.

Giri, S., Idle, J. R., Chen, C., Zabriskie, T. M., Krausz, K. W., \& Gonzalez, F. J. (2006). A metabolomic approach to the metabolism of the areca nut alkaloids arecoline and arecaidine in the mouse. Chemical Research in Toxicology, 19(6), 818-827.

Gupta, S. C., Siddique, H. R., Saxena, D. K., \& Chowdhuri, D. K. (2005). Comparative toxic potential of market formulation of two organophosphate pesticides in transgenic Drosophila melanogaster (hsp70-lacZ). Cell Biology and Toxicology, 21(3-4), 149-162.

Habig, W. H., Pabst, M. J., Fleischner, G., Gatmaitan, Z., Arias, I. M., \& Jakoby, W. B. (1974). The identity of glutathione S-transferase B with ligandin, a major binding protein of liver. Proceedings of the National Academy of Sciences, 71(10), 3879-3882.

Hawkins, C. L., Morgan, P. E., \& Davies, M. J. (2009). Quantification of protein modification by oxidants. Free Radical Biology and Medicine, 46(8), 965-988.

Herz, A., Fraling, F., Niedner, I., \& Färber, G. (1967). Pharmacologically induced alterations of cortical and subcortical evoked potentials compared with physiological changes during the awake-sleep cycle in cats. Electroencephalogr Clin Neurophysiol. Suppl 26:164+

Holden, M., \& Kelly, C. (2002). Use of cholinesterase inhibitors in dementia. Advances in Psychiatric Treatment, 8(2), 89-96.

Jeng, J. H., Chang, M. C., \& Hahn, L. J. (2001). Role of areca nut in betel quidassociated chemical carcinogenesis: Current awareness and future perspectives. Oral Oncology, 37(6), 477-492.

Jeng, J. H., Tsai, C. L., Hahn, L. J., Yang, P. J., Kuo, Y. S., \& Kuo, M. Y. P. (1999). Arecoline cytotoxicity on human oral mucosal fibroblasts related to cellular thiol and esterase activities. Food and Chemical Toxicology, 37(7), 751-756.

Jeng, J. H., Wang, Y. J., Chiang, B. L., Lee, P. H., Chan, C. P., Ho, Y. S., ... Chang, M. C. (2003). Roles of keratinocyte inflammation in oral cancer: Regulating the prostaglandin E 2, interleukin-6 and TNF-a production of oral epithelial cells by areca nut extract and arecoline. Carcinogenesis, 24(8), 1301-1315.

Jollow, D. J., Mitchell, J. R., Zampaglione, N. A., \& Gillette, J. R. (1974). Bromobenzene-induced liver necrosis. Protective role of glutathione and evidence for 3, 4-bromobenzene oxide as the hepatotoxic metabolite. Pharmacology, 11(3), 151-169.
Jyoti, S., Khan, S., Afzal, M., Naz, F., \& Siddique, Y. H. (2013). Evaluation of micronucleus frequency by acridine orange fluorescent staining in bucccal epithelial cells of oral submucosus fibrosis (OSMF) patients. Egyptian Journal of Medical Human Genetics, 14(2), 189-193.

Jyoti, S., Naz, F., Khan, S., Ali, F., Fatima, A., Khanam, S., \& Siddique, Y. H. (2014). Detection of aneugenicity and clastogenicity in buccal epithelial cells of pan masala and gutkha users by pan-centromeric FISH analysis. Mutagenesis, 30(2), 263-267.

Jyoti, S., Siddique, Y. H., Khan, S., Naz, F., \& Ali, F. (2015). Effect on micronucleus frequency and DNA damage in buccal epithelial cells of various factors among pan masala and gutkha chewers. Oral Science International, 12(1), 9-14.

Kevekordes, S., Spielberger, J., Burghaus, C. M., Birkenkamp, P., Zietz, B., Paufler, P., ... Dunkelberg, H. (2001). Micronucleus formation in human lymphocytes and in the metabolically competent human hepatoma cell line Hep-G2: Results with 15 naturally occurring substances. Anticancer Research, 21(1A), 461-469.

Kumar, A., \& Singh, A. (2015). A review on Alzheimer's disease pathophysiology and its management: An update. Pharmacological Reports, 67(2), 195-203.

Kumar, S., \& Doumanis, J. (2000). The fly caspases. Cell Death and Differentiation, 7(11), 1039.

Kumpawat, K., Deb, S., Ray, S., \& Chatterjee, A. (2003). Genotoxic effect of raw betel-nut extract in relation to endogenous glutathione levels and its mechanism of action in mammalian cells. Mutation Research/Genetic Toxicology and Environmental Mutagenesis, 538(1), 1-12.

Liu, Y. J., Peng, W., Hu, M. B., Xu, M., \& Wu, C. J. (2016). The pharmacology, toxicology and potential applications of arecoline: A review. Pharmaceutical Biology, 54(11), 2753-2760.

Long, J., Gao, H., Sun, L., Liu, J., \& Zhao-Wilson, X. (2009). Grape extract protects mitochondria from oxidative damage and improves locomotor dysfunction and extends lifespan in a Drosophila Parkinson's disease model. Rejuvenation Research, 12(5), 321-331.

Mazzoni, P., Shabbott, B., \& Cortés, J. C. (2012). Motor control abnormalities in Parkinson's disease. Cold Spring Harbor Perspectives in Medicine, 2(6), a009282.

McEwan, C. M. (1965). Human plasma monoamine oxidase. The Journal of Biological Chemistry, 240, 2003-2010.

Mukhopadhyay, I., Saxena, D. K., \& Chowdhuri, D. K. (2003). Hazardous effects of effluent from the chrome plating industry: $70 \mathrm{kDa}$ heat shock protein expression as a marker of cellular damage in transgenic Drosophila melanogaster (hsp70-lacZ). Environmental Health Perspectives, 111(16), 1926.

Ohkawa, H., Ohishi, N., \& Yagi, K. (1978). Reaction of linoleic acid hydroperoxide with thiobarbituric acid. Journal of Lipid Research, 19(8), 1053-1057.

Pai, S. B. (1983). Evaluation of mutagenic effect of the fungicide fenaminosulf in Drosophila melanogaster. Mutation Research Letters, 119(3-4), 289-291.

Pandey, A., Chandra, S., Chauhan, L. K. S., Narayan, G., \& Chowdhuri, D. K. (2013). Cellular internalization and stress response of ingested amorphous silica nanoparticles in the midgut of Drosophila melanogaster. Biochimica et Biophysica Acta (BBA)-General Subjects, 1830(1), 2256-2266.

Papke, R. L., Horenstein, N. A., \& Stokes, C. (2015). Nicotinic activity of arecoline, the psychoactive element of "betel nuts", suggests a basis for habitual use and anti-inflammatory activity. PLoS One, 10(10), e0140907.

Pendleton, R. G., Parvez, F., Sayed, M., \& Hillman, R. (2002). Effects of pharmacological agents upon a transgenic model of Parkinson's disease in Drosophila melanogaster. Journal of Pharmacology and Experimental Therapeutics, 300(1), 91-96.

Podder, S., \& Roy, S. (2015). Study of the changes in life cycle parameters of Drosophila melanogaster exposed to fluorinated insecticide, cryolite. Toxicology and Industrial Health, 31(12), 1341-1347.

Raffaele, K. C., Asthana, S., Berardi, A., Haxby, J. V., Morris, P. P., Schapiro, M. B., \& Soncrant, T. T. (1996). Differential response to the cholinergic agonist arecoline among different cognitive modalities in Alzheimer's disease. Neuropsychopharmacology, 15(2), 163.

Rajak, P., Dutta, M., Khatun, S., Mandi, M., \& Roy, S. (2017). Exploring hazards of acute exposure of Acephate in Drosophila melanogaster and search for I-ascorbic acid mediated defense in it. Journal of Hazardous Materials, 321, 690-702.

Rand, M. D. (2010). Drosophotoxicology: The growing potential for Drosophila in neurotoxicology. Neurotoxicology and Teratology, 32(1), 74-83.

Richardson, J. S. (1993). On the of monoamine oxidase, the emotions, and adaptation to stress. International Journal of Neuroscience, 70(1-2), 75-84.

Rosato, E., \& Kyriacou, C. P. (2006). Analysis of locomotor activity rhythms in Drosophila. Nature Protocols, 1(2), 559.

Run-mei, X., Jun-jun, W., Jing-ya, C., Li-juan, S., \& Yong, C. (2014). Effects of arecoline on hepatic cytochrome P450 activity and oxidative stress. The Journal of Toxicological Sciences, 39(4), 609-614. 
Shakya, B., \& Siddique, Y. H. (2018). Evaluation of the toxic potential of arecoline toward the third instar larvae of transgenic Drosophila melanogaster (hsp70lacZ) Bg 9. Toxicology Research, 7(3), 432-443.

Shih, Y. T., Chen, P. S., Wu, C. H., Tseng, Y. T., Wu, Y. C., \& Lo, Y. C. (2010) Arecoline, a major alkaloid of the areca nut, causes neurotoxicity through enhancement of oxidative stress and suppression of the antioxidant protective system. Free Radical Biology and Medicine, 49(10), 1471-1479.

Siddique, Y. H., Ara, G., Jyoti, S., Naz, F., \& Afzal, M. (2011). Protective effect of Apigenin against Ethinylestradiol induced toxic effects in the third instar larvae of transgenic Drosophila melanogaster (hsp70-lacZ) Bg ${ }^{9}$. Pharmacologyonline, 3, 667-684

Siddique, Y. H., Jyoti, S., \& Naz, F. (2014). Effect of epicatechin gallate dietary supplementation on transgenic Drosophila model of Parkinson's disease. Journal of Dietary Supplements, 11(2), 121-130.

Singh, P. \& Chowdhuri, D. K. (2017). Environmental presence of hexavalent but not trivalent chromium causes neurotoxicity in exposed Drosophila melanogaster. Molecular Neurobiology, 54(5), 3368-3387.

Singla, N., \& Dhawan, D. K. (2013). Zinc, a neuroprotective agent against aluminum-induced oxidative DNA injury. Molecular Neurobiology, 48(1), 1-12.

Sullivan, R. J., Andres, S., Otto, C., Miles, W., \& Kydd, R. (2007). The effects of an indigenous muscarinic drug, betel nut (Areca catechu), on the symptoms of schizophrenia: a longitudinal study in Palau, Micronesia. American Journal of Psychiatry, 164(4), 670-673.

Tseng, S-K., Chang M-C., Su, Ch-Y, Chi, L-Y., Chang, J. Z-C., Tseng, W-Y., Yeung, S-Y, Hsu, M-L., \& Jeng, J-H. (2012). Arecoline induced cell cycle arrest, apoptosis, and cytotoxicity to human endothelial cells. Clin Oral Investig 16(4), 1267-1273.

Zhou, J., Sun, Q., Yang, Z., \& Zhang, J. (2014). The hepatotoxicity and testicular toxicity induced by arecoline in mice and protective effects of vitamins $C$ and E. The Korean Journal of Physiology \& Pharmacology, 18(2), 143-148.

\section{Submit your manuscript to a SpringerOpen ${ }^{\circ}$ journal and benefit from:}

- Convenient online submission

- Rigorous peer review

- Open access: articles freely available online

- High visibility within the field

- Retaining the copyright to your article

Submit your next manuscript at $\boldsymbol{\nabla}$ springeropen.com 